\title{
Case Studies As Practical Teaching In The New Marketing Courses
}

Juan-Antonio Mondéjar-Jiménez, Ph.D., University of Castilla-La Mancha, Spain María Cordente-Rodríguez, University of Castilla-La Mancha, Spain

Miguel-Ángel Gómez-Borja, Ph.D., University of Castilla-La Mancha, Spain

María-Encarnación Andrés-Martínez, University of Castilla-La Mancha, Spain Juan-Carlos Gázquez-Abad, Ph.D., University of Almería, Spain

\begin{abstract}
The European Higher Education Area is assuming a change in the teaching-learning of all European universities. The area of Marketing, traditionally characterized by being at the forefront in terms of educational innovation, faces the challenge of finding new tools to facilitate the work of students by encouraging their involvement in the acquisition of new skills. This paper analyzes the capacity that the development of case studies has to develop skills and competencies by the students, which are defendants in the framework of the European Higher Education Area to suit the environment established in the labor market. To this end, it is analyzed the experience and the main conclusions of the practices carried out at the University of Castilla-La Mancha, with the participation of student groups at an international conference aimed at developing teaching cases in public and nonprofit marketing.
\end{abstract}

Keywords: Teaching methodologies; case studies; European Higher Education Area

\section{INTRODUCTION}

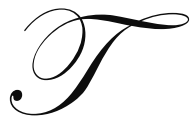

he creation of a European Higher Education Area, whose statement was signed in Bologna in 1999, was based on the principles of quality, mobility, diversity and competitiveness.

To this end it was designed a process of convergence of educational structures, removing existing barriers; the process was implemented by four strands (Gómez, Puig, Quirós and Viaño, 2004):

- $\quad$ Adoption of a system of titles of easy interpretation and comparison, by setting up a European Diploma Supplement.

- $\quad$ Adoption of a structure of two cycles: undergraduate and graduate.

- $\quad$ Adoption of a common system of credits (ECTS).

- Promotion of European cooperation in the development of methodologies and criteria for evaluation and accreditation of comparable quality.

The convergence process in Spain has been reflected in an improvement plan for the university system, from three key points:

- $\quad$ Redefine the qualifications as professional profiles considering the labor market.

- $\quad$ Move program content and skills objectives to on learning outcomes.

- Adapt teaching methods to an education considered from learning, in which it is made reality the old slogan of a university designed for the student to learn to learn and for the teacher to teach to learn.

The European Higher Education Area that we face in Europe wants to adapt to an increasingly competitive market (Gibbs, 2007). 
Thus, it is necessary that universities are aware of the need to adapt their training programs and teaching methods employed on the new undergraduate and graduate degrees (Barber, 2008, Pusztai and Szabo, 2008).

The adequacy of this new university system forces to change the current dynamics of teaching and learning, where students have a more active role, so take responsibility, being responsible for their own learning (Whitehead, 2008), preparing for social and professional changes which are required in the market (De Juan, Gonzalez, Parra, Kanther and Sarabia, 2008). In this way they develop skills that help them cope with a changing work environment, competitive and complex (Hunt, Eagle and Kitchen, 2004).

In this context, teachers must be able to contribute to the development of pupil skills and also make sure that they will be able to apply them in the workplace (Canzer, 1997).

Active learning facilitates the development of skills, which would be difficult to acquire with a passive learning, such as leadership, people management, group work or distribution of tasks (Wright, Bitner and Zeithaml, 1994, Adrian and Palmer, 1999).

The objective of this ongoing work is to show the experience with the methodology of case studies conducted at the University of Castilla-La Mancha, which allowed the development of certain skills, assimilate knowledge and implementation of knowledge acquired.

\section{CASE STUDIES}

The use of the methodology of case study is widely recognized in the education of the business and very appropriate for this area of study. However, the debate over the use of this methodology focuses on how students should approach the case study and how it should be the teaching process (Parkinson, 2008).

There are different opinions on what constitutes a case and what are the educational objectives of the same (Parkinson, 2008). Thus, the appropriate choice of cases depends on contextual factors, in particular, the end of the use of a case and distinguishes between:

- $\quad$ Cases used to evaluate (Michlitsch and Sidle, 2002; Parkinson, 1999).

- $\quad$ Cases used for student learning.

One of the reasons that support the use of case studies is that they allow a higher level of learning (Bloom, Englehart, Furst, Hill and Krathwohl, 1956, Andrews and Krathwol, 2001), since the cases can exercise the educational objectives: comprehension, application, analysis, synthesis and evaluation.

The essential feature of a case is to choose the subject of it (Chrisman, 1990; Naumes, 1989, Campbell and Lewis, 1991). In the simplest cases, you can request information to evaluate, but in others more complex, you can ask the student to choose an issue and solve it, starting with the establishment of a set theme.

As for the outcome of cases, Parkinson and Taggar (2006) conclude that the results vary depending on the personality of the writers of the case. So, for those with creative personality achieve good results in identifying the problem, while those that act more conscientiously perform better results in the analysis of the problem.

\section{Characteristics}

Some authors suggest the usefulness of case studies in terms of the debate between reality and fiction. For example Naumes (1989) argues that case studies should be based on reality, to represent events that have occurred and thus stimulate the debate. The benefit of working with real cases, is to help to develop the ability to search all the facts surrounding the case, a situation to which a director has to face in today's job market.

At the other extreme is the alternative to work with an invented case or case of "armchair", this option allows to focus the case on a specific aspect of an item you want to work. With the ability to be a case entirely invented or the grouping of different situations from real cases. 
Another feature that is discussed in the use of case studies is theirs length. Thus, Chrisman (1990) argues that a good case should contain as much information as possible about the situation facing the company. This should include information about the organization's main competitors, suppliers and customers, also on political, social, legal and economic environment of the organization. The case also should describe the objectives and strategies of the company, products and services offered to the market, and the advantages and disadvantages possessed by the organization.

While on the contrary some authors consider that a case too long is difficult to handle, and it is more convenient a short case, focused on the objective aspect under consideration in the case, to avoid wasting too much time getting acquainted with the company. 1998).

Therefore, to adapt to the educational objectives it is necessary to limit the scope of the case study (Erskine,

\section{The role of the teacher-tutor}

The type of case, namely, the distinction between directed and undirected case, it becomes a key element for the probability of success.

So the teacher-tutor may choose four perspectives when he works with case studies (Eisenbeis, 1994):

- Facilitator: it has a minimal role in the process of interaction, allowing students to develop their analysis with their own efforts. It may give rise to higher levels of creativity and learning.

- Coach: students are still responsible, but the teacher has more interaction by asking questions and clarifying doubts. This will lead to skills in analytical reasoning.

- $\quad$ Quarterback: teacher heavily involved in guiding students in the right direction.

- Demonstrator: the teacher shows the correct solution and how to get it, asking in a few cases the students involvement

\section{PRACTICE RESULTS}

The implementation of this practice stems from the initiative of the International Association of Public and Non Profit Marketing (AIMPN/IAPNM) in collaboration with the Department Bancaja Young Entrepreneurs of the University of León, which organized the First International Conference on Teacher Case Public and Nonprofit Marketing, under the theme "Entrepreneurs, Business and Administration in a Socially Responsible World".

The purpose of this conference is to provide a forum for debate to highlight the concerns of teachers and students on issues related to social responsibility of operations carried out by entrepreneurs, entities of the business and public sector.

The case studies should contain information on actual marketing activities of any kind carried out by companies, public or nonprofit institutions that are particularly noteworthy because of their socially responsible.

The teams were made up of a maximum of five students who developed a case study under the supervision of a teacher-tutor.

First, each working group should investigate examples of companies that carry out socially responsible practices, and secondly, they should choose one and finally they had to prepare a document with the information they consider relevant to show the company practices and defend their socially responsible behavior.

For the selection of the company to consider, initially, students had to work the concept of social responsibility, then choose an example they consider socially responsible and finally at a length of between 5 and 10 pages to explain the behavior and practices responsible for their example and criticize and comment on it. 
The role played by the teacher at this point is that of facilitator, and merely suggest the topic of study and provide a template, with the structure that the case must have for shipping, while leaving total freedom to students to select the cases they want analyzed and the content they wish to communicate.

The call for this activity among the students of 4th year Bachelor of Administration and Management was successful in terms of participation, where what was rewarded was not the participation, as it was a voluntary activity, but the selection of appropriate study to represent the university in the conference.

For students, the bonus was reflected in the award of a diploma certifying their participation and obtain a copy of the publication in electronic form provided ISBN and supported by an International Scientific Committee, in this publication, each of the cases appeared as a chapter of that publication. This type of reasoning is in line with what Bandura (1986) calls "performance expectations" based on the achievement of some kind of reward.

All cases presented represent real situations of the companies analyzed, and covered in them as much information as possible about the situation facing the company referred to the area of social responsibility.

\section{CONCLUSIONS}

Although this is a paper which has a goal of continuity in the future can be identified as preliminary conclusion of the performance contribution of this activity by self-learning students from having a passive role to awaken in them a proactivity, which allows them to engage in class and be protagonist and responsible of their learning as establishing the new university, to break with traditional models of teaching where the teachers set a master class for students to perform and memorize.

This article highlights the importance of using the methodology of case studies to deepen specific aspects of learning. But it is also relevant to the acquisition of skills and abilities that will help them navigate the changing labor market, competitive and complex that currently exists.

It should also be noted the motivation that students had in participating in this activity, because for them it represented the possibility that the work that had been developed could be published.

The introduction of new degree requires innovative teaching methods, so this experience will be beneficial in the subject area of Marketing and Market Research.

In addition, the role of "facilitator" adopted by the teacher-tutor in the first place allows students to achieve a high level of learning, because they themselves who care to seek information, understand, analyze and synthesize.

The future research of the early results of the practice of case studies to be drawn from this study, with an intention to continue implementing this methodology in order to obtain more comprehensive findings as part of a larger educational innovation.

\section{AUTHOR INFORMATION}

Juan-Antonio Mondéjar-Jiménez: PhD and Degree in Business Administration by University of Castilla-La Mancha. Degree in Advanced Studies in Marketing at the same university. Associate Professor in Marketing at Business Department. Faculty of Social Sciences of Cuenca. University of Castilla-La Mancha (Spain). E-mail: JuanAntonio.Mondejar@uclm.es

Research Interest: Consumer behavior, price perception, e-learning and tourism marketing.

María Cordente-Rodríguez: Degree in Business Administration by University of Castilla-La Mancha. Lecturer in Marketing at Business Administration Department. Faculty of Social Sciences of Cuenca. University of Castilla-La Mancha (Spain). E-mail: Maria.Cordente@uclm.es

Research Interest: Tourism marketing, consumer behavior and e-learning. 
Miguel-Ángel Gómez-Borja: Degree in Economics and Business from University of Valencia (Spain). and PhD on E-Marketing from University of Castilla-La Mancha (Spain). Currently Associate Professor in Marketing at Business Administration Department. Faculty of Economics and Business Administration of Albacete, University of Castilla-La Mancha (Spain). E-mail: MiguelAngel.GBorja@uclm.es

Research Interest: Electronic commerce, Web 2.0, Social Networking consumer behaviour, marketing research, experimental designs, and quantitative analysis.

María-Encarnación Andrés Martínez: Degree in Business Administration by University of Castilla-La Mancha. Assistant Professor in Marketing at Business Administration Department. Faculty of Economics and Business Administration of Albacete. University of Castilla-La Mancha (Spain). E-mail: Encarnacion.Andres@uclm.es. Research Interest: consumer behaviour, price perception, internet and tourism.

Juan-Carlos Gázquez-Abad: $\mathrm{PhD}$ and Degree in Business Administration by University of Almería. Associate Professor in Marketing at Business Department. Faculty of Business and Economics, University of Almería (Spain). E-mail: jcgazque@ual.es

Research Interest: Consumer behavior, retailing, sales promotions

\section{REFERENCES}

1. Adrian, C.M. \& Palmer, G.D. (1999): "Toward a Model for Understanding and Improving Educational Quality in the Principles of Marketing Course". Journal of Marketing Education, Vol. 21, $\mathrm{n}^{\circ} 1$ (April), pgs. 25-34.

2. Andrews, L.W. \& Krathwohl, D. (2001): A Taxonomy for Learning, Teaching and Assessing: a Revision of Bloom's Taxonomy of Educational Objectives, Longman. New York.

3. Bandura, A. (1986): Social Foundations of Thought and Action: A Social Congnitive Theory, Prentice.Hall, Englewood Cliffs, NJ.

4. $\quad$ Barber, M. (2008): “A formula for great teaching”, Times Educational Supplement, Vol. 48, pgs. 19-29.

5. Bloom, B.S.; Englehart, M.D.; Furst, G.J.; Hill, W.H. \& Krathwohl, D.R. (1956): Taxonomy of Educational Objectives: the Cognitive Domain. New York.

6. Cambell, J.E. \& Lewis, W.F. (1999): "Using Cases in Accounting Classes", Issues in Accounting Education, Vol. 6, n², pgs. 276-283.

7. Canzer, B. (1997): "Marketing education on the internet: a world wide web based introductory marketing course design for the virtual-u project in distance education at Simon Fraser University", Journal of Marketing Education, Vol. 23, n ${ }^{\circ}$. 1, pgs. 56-65.

8. Chrisman, J.J. (1990): “Writing Publishable Cases: Some Guidelines”, Case Research Journal, Spring, pgs. 4-9.

9. De Juan, M.D.; González, E.; Parra, J.F.; Kanther, A. \& Sarabia, F.J. (2008): “Antecedentes del aprendizaje autorregulado del estudiantes universitario de marketing", XX Encuentro de Profesores Universitario de Marketing, Las Palmas de Gran Canaria.

10. Eisenbeis, H. (1994): "Using the Facilitator Role in Case Teaching: a Personal Perspective", Case Research Journal, Vol 14, nº 2, pgs.121-133.

11. Erskine, J.A.; Leenders, M.R. \& Mauffette-Leenders, L.A. (1998): Teaching with Cases, University of Western Ontario, London, ON.

12. Gibbs, P. (2007): "Editorial”, Journal of Business Research, Vol. 60, n 9, pgs. 925-926.

13. Gómez, B.; Puig, L.; Quirós, A. \& Viaño, J.M. (2004): "La convergencia europea en educación y las nuevas leyes educativas españolas (Lou y Loce)”, Jornadas sobre Educación Matemática: La Educación Matemática en la Europa del siglo XXI, Santiago. Consellería de Educación/ AGAPEMA/FESPM, RSME y SEIEM.

14. Hunt, L.; Eagle, L. \& Kitchen, P. (2004): "Balancing marketing education and information technology: Matching needs or needing a better match?", Journal of Marketing Education, Vol. 26, nº. 1, pgs.75-88.

15. Mitchlistch, J.F. \& Sidle, M.W. (2002): “Assessing student learning outcomes: a comparative study of techniques used in business school disciplines", Journal of Education for Business, Vol. 77, pgs.125 - 130.

16. Naumes, W. (1989): "Case Writing, Professional Development and Publishing Standards: Guidelines for the Case Research Journal”, Case Research Journal, Vol. 23, n 1 y 2, pgs. 145-150. 
17. Parkinson, J.M. (1999): "Differences in the Assessment of Case Studies", 16th International Conference on Case Method \& Case Application, Cáceres, Spain.

18. Parkinson, J.M. (2008): “Case Studies And How They Are Used”, Journal of Business Case Studies, Vol. $4, \mathrm{n}^{\mathrm{o}} 12$.

19. Parkinson, J.M. \& Taggar, S. (2006): "Intelligence, Personality and Performance on Case Studies", Journal of Business \& Psychology, published online.

20. Pusztai, G. \& Szabo, P.C. (2008): "The Bologna process as a Trojan horse", European Education, Vol. 40, n 2 , pgs. 85-103.

21. Whitehead, D.P. (2008): “Thoughts on Education and Innovation", Childhood Education, Vol. 85, n 2, pgs. 106-118.

22. Wright, L.K.; Bitner, M.J. \& Zeithaml, V.A. (1994): "Paradigm shifts in business education: using active learning to deliver services marketing content”, Journal of Marketing Education, Vol. 16, pgs. 5-19. 